\title{
Gambaran histopatologik lambung tikus Wistar (Rattus norvegicus) yang diinduksi asam mefenamat dan diberi susu kental manis
}

\author{
${ }^{1}$ Aisyah Nurul Shafira \\ ${ }^{2}$ Carla F. Kairupan \\ ${ }^{2}$ Meilany F. Durry \\ ${ }^{1}$ Kandidat Skripsi Fakultas Kedokteran Universitas Sam Ratulangi Manado \\ ${ }^{2}$ Bagian Patologi Anatomi Fakultas Kedokteran Universitas Sam Ratulangi Manado \\ Email: anshafira30@gmail.com
}

\begin{abstract}
Empirically, sweet condensed milk is often consumed by gastritis patients with acute gastritis to relieve the symptoms of epigastric pain. Its amphoteric acidity ( $\mathrm{pH} 6,5-6,7$ ), sweet taste, nutritional and oligosaccharides contents are some factors that are predicted to influence the relieve of epigastric pain. Acute gastritis can be induced by NSAIDs, such as mefenamic acid. This study aimed to reveal the histopathological features of the gaster of Wistar rats (Rattus norvegicus) induced with mefenamic acid and fed with sweet condensed milk. This was laboratory experimental study using 21 Wistar rats. Rats were divided into three groups (seven rats in each group). Group A was the negative control, group B was induced with mefenamic acid 23,25 mg/day for seven days, and group C were induced with mefenamic acid 23,25 mg/day and administered with sweet condensed milk $0,8 \mathrm{ml} /$ day simultaneously for seven days. All rats were terminated on day 8. The results showed that histopathological features of the gaster of Wistar rats had less inflammatory cells and more regenerated cells than that of rats in group B. Conclusion: Histopathological features of gaster of Wistar rats induced with mefenamic acid and treated with sweet condensed milk showed milder signs of acute gastritis and better cell regeneration than that of Wistar rat not treated with sweet condensed milk.
\end{abstract}

Keywords: Sweet Condensed Milk, Acute Gastritis, Histopathological

\begin{abstract}
Abstrak: Berdasarkan pengalaman empiris, susu kental manis sering dikonsumsi oleh penderita gastritis akut untuk meredakan keluhan nyeri epigastrium pasien. Sifat amfoter (pH 6,5 - 6,7), rasa manis, kandungan nutrisi, dan oligosakarida susu merupakan faktor-faktor yang diduga berpengaruh terhadap perbaikan keluhan tersebut. Penyakit gastritis akut dapat diinduksi dengan obat AINS, salah satunya asam mefenamat. Tujuan penelitian ini ialah untuk mengetahui gambaran histopatologik lambung tikus wistar (Rattus norvegicus) yang diinduksi asam mefenamat dan diberi susu kental manis. Penelitian eksperimental ini menggunakan subyek 21 ekor tikus wistar yang dibagi dalam tiga kelompok (tujuh ekor tikus setiap kelompok). Kelompok A tidak diberi perlakuan, kelompok B diberi asam mefenamat $23,25 \mathrm{mg} / \mathrm{tikus} /$ hari selama tujuh hari, dan kelompok $\mathrm{C}$ diberi asam mefenamat 23,25 mg/tikus/hari dan susu kental manis $0,8 \mathrm{ml} /$ tikus/hari secara bersamaan selama tujuh hari. Semua tikus diterminasi pada hari ke-8. Hasil penelitian ini menunjukkan gambaran histopatologik lambung tikus wistar berupa infiltrat sel-sel radang yang lebih sedikit serta sel-sel regenerasi yang lebih aktif dan banyak pada kelompok $\mathrm{C}$ jika dibandingkan dengan yang terlihat pada kelompok $\mathrm{B}$. Simpulan: Gambaran histopatologik lambung tikus wistar yang diinduksi asam mefenamat dan diberi susu kental manis menunjukkan tanda-tanda gastritis akut yang lebih ringan dan regenerasi sel yang lebih baik dibandingkan dengan yang terlihat pada lambung tikus wistar yang diinduksi asam mefenamat tetapi tidak diberi susu kental manis.
\end{abstract}

Kata kunci: Susu Kental Manis, Gastritis Akut, Histopatologik 
Berdasarkan pengalaman empiris, susu kental manis (SKM) sering dikonsumsi oleh penderita gastritis akut untuk meredakan keluhan nyeri epigastrium. Susu kental manis adalah susu sapi yang airnya dihilangkan dan ditambahkan gula, sehingga menghasilkan susu yang sangat manis. Susu merupakan produk makanan yang bersifat amfoter, yaitu dapat bersifat asam dan basa sekaligus, dengan $\mathrm{pH}$ berkisar antara 6,5-6,7..$^{1}$ Rasa manis dan $\mathrm{pH}$ dari susu kental manis diduga menjadi hal yang mendasari perbaikan keluhan dari pasien gastritis. Selain itu, kandungan oligosakarida susu yang memiliki efek antipatogenik terhadap saluran cerna dapat menghambat perlekatan $H$. pylori pada mukosa lambung, sehingga menurunkan risiko terjadinya erosi pada mukosa. ${ }^{2}$

Gastritis merupakan suatu keadaan peradangan atau perdarahan mukosa lambung yang bersifat akut, kronis, difus, atau lokal. ${ }^{3}$ Pada gastritis akut dapat ditemukan perubahan-perubahan histopatologik berupa degradasi epitel, hiperplasia foveolar, infiltrasi netrofil, infiltrasi sel mononuklear, folikel limfoid, atropi, metaplasia intestinal, hiperplasia sel endokrin, dan kerusakan sel epitel. Terdapat spektrum keparahan yang bervariasi dari yang sangat lokal (cedera akibat AINS) hingga difus dan dari peradangan superfisial sampai keterlibatan seluruh ketebalan mukosa disertai perdarahan dan nekrosis fokal. ${ }^{4}$

Obat anti-inflamasi non steroid (AINS) diketahui mengganggu sawar mukosa lambung sehingga dapat mencetus peradangan mukosa lambung. ${ }^{4,5}$ Salah satu obat AINS yang sering digunakan oleh masyarakat ialah asam mefenamat. Asam mefenamat tergolong dalam kelompok AINS COX-nonselektif. Golongan obat ini menghambat enzim siklooksigenase (COX) sehingga konversi asam arakidonat menjadi $\mathrm{PGG}_{2}$ terganggu. Di mukosa lambung, aktivasi COX-1 menghasilkan prostasiklin yang bersifat sitoprotektif. ${ }^{5}$

Mekanisme terjadinya iritasi lambung akibat AINS bersifat lokal dan sistemik.
Iritasi lokal menimbulkan difusi kembali asam lambung ke mukosa sehingga menyebabkan kerusakan jaringan. Iritasi sistemik melalui hambatan biosintesis $\mathrm{PGE}_{2}$ dan $\mathrm{PGI}_{1}$ menyebabkan iritasi hingga perdarahan lambung. Kedua PG ini banyak ditemukan di mukosa lambung dengan fungsi menghambat asam lambung dan merangsang sekresi mukus yang bersifat sitoprotektif. ${ }^{5}$ Efek yang menghambat sintesis prostaglandin ini dapat menjelaskan peranan obat AINS dalam iritasi mukosa lambung.,

Berdasarkan pernyataan di atas, peneliti terdorong melakukan penelitian yang bertujuan untuk mengetahui gambaran histopatologik lambung tikus wistar (Rattus norvegicus) yang diinduksi asam mefenamat dan diberi susu kental manis.

\section{METODE PENELITIAN}

Penelitian ini merupakan penelitian eksperimental laboratorik yang dilakukan pada bulan September - Desember 2016 di Laboratorium Patologi Anatomi Fakultas Kedokteran Universitas Sam Ratulangi Manado. Subjek penelitian yang digunakan ialah 21 ekor tikus wistar (Rattus norvegicus) dewasa dengan berat rata-rata 150-200 gram. Asam mefenamat yang digunakan ialah asam mefenamat kaplet $500 \mathrm{mg}$. Asam mefenamat 23,25 mg dalam $1 \mathrm{ml}$ akuades diberikan sekali sehari. Susu kental manis yang digunakan adalah susu kental manis kemasan kaleng (merek Frisian Flag). Susu kental manis $0,8 \mathrm{ml}$ diberikan sekali sehari. Asam mefenamat dan susu kental manis diberikan secara oral dengan sonde lambung yang dibuat khusus untuk tikus.

Subjek penelitian dibagi dalam 3 kelompok. Kelompok A (kelompok kontrol negatif), tikus tidak diberi perlakuan selama 7 hari dan diterminasi pada hari ke-8; kelompok B (kelompok perlakuan I), tikus diberi asam mefenamat selama 7 hari dan diterminasi pada hari ke8; dan kelompok C (kelompok perlakuan II), tikus diberi asam mefenamat dan susu 
kental manis secara bersamaan selama 7 hari dan diterminasi pada hari ke-8. Organ lambung diproses untuk pembuatan preparat histopatologik dan dievaluasi gambaran mikroskopik jaringan lambung.

\section{HASIL PENELITIAN}

Pada tikus wistar kelompok A (kontrol negatif) diperoleh gambaran histologik lambung yang normal. Lapisan mukosa, submukosa, muskularis, dan serosa dalam keadaan normal dan menunjukkan adanya sedikit sel-sel radang pada lapisan mukosa. (Lihat Gambar 1).

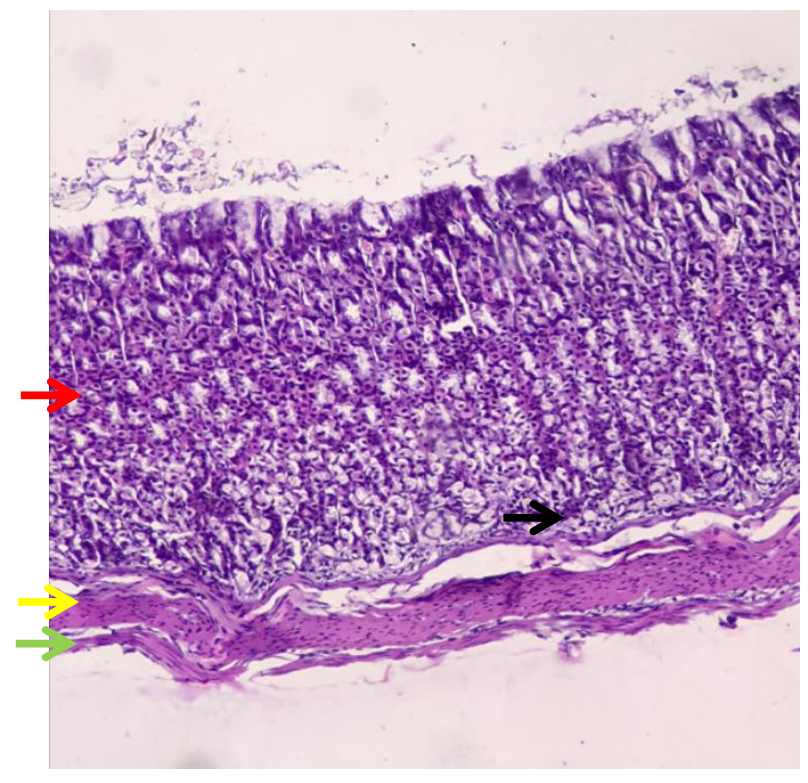

Gambar 1. Gambaran mikroskopik lambung tikus wistar kelompok A. (Panah merah: lapisan mukosa; panah kuning: lapisan submukosa; panah hijau: lapisan muskularis; panah hitam: sel-sel radang)

Pada tikus wistar kelompok B diperoleh gambaran histopatologik yang memperlihatkan tanda-tanda radang, yaitu infiltrasi sel-sel radang PMN, limfosit, sel plasma dan eosinofil dalam jumlah banyak pada lapisan mukosa, submukosa, muskularis, hingga serosa. Terdapat pula jaringan stroma hiperemis, pelebaran pembuluh darah kapiler, atrofi epitel mukosa serta edema jaringan. Pada lapisan mukosa tampak sedikit erosi epitel pada beberapa area. Pada kelompok ini juga terlihat beberapa sel yang mulai regenerasi. (Lihat Gambar 2).

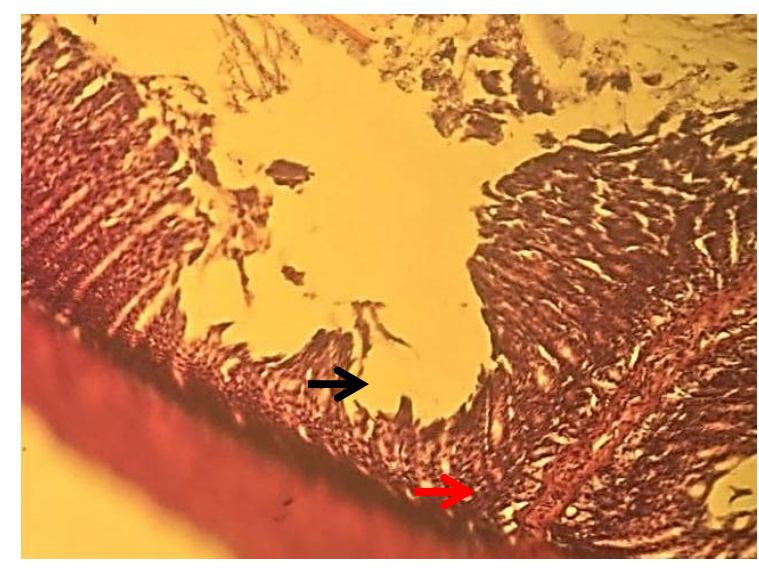

Gambar 2.1. Gambaran mikroskopik lambung tikus wistar kelompok B. Tampak erosi epitel permukaan mukosa dan sel-sel radang (Panah hitam: erosi; panah merah: sel-sel radang)

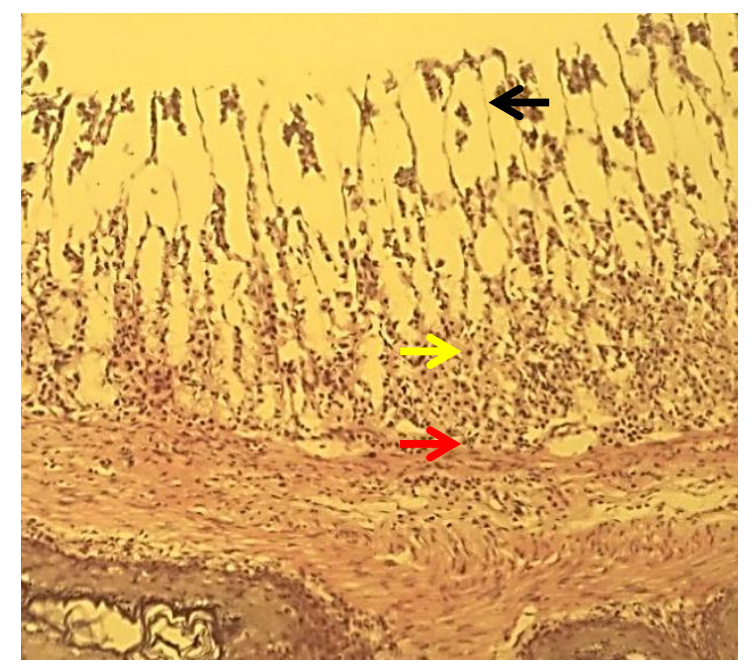

Gambar 2.2. Gambaran mikroskopik lambung tikus wistar kelompok B. Tampak atrofi epitel permukaan mukosa dan sel-sel radang. Terdapat beberapa sel regenerasi (Panah hitam: artofi; Panah merah: sel-sel radang; Panah kuning: sel regenerasi) 


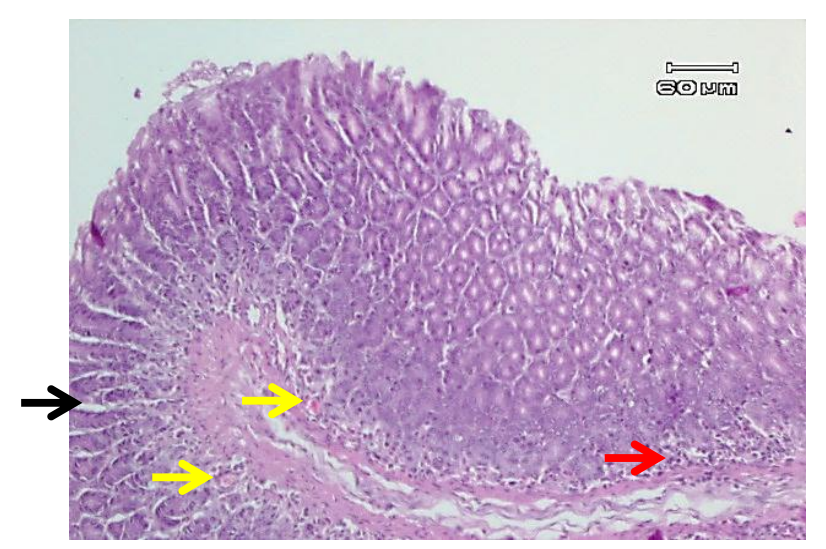

Gambar 2.3. Gambaran mikroskopik lambung tikus wistar kelompok B. Tampak edema jaringan, sel-sel radang, dan pembuluh darah yang melebar (Panah hitam: edema; panah merah: sel-sel radang; panah kuning: vasodilatasi)

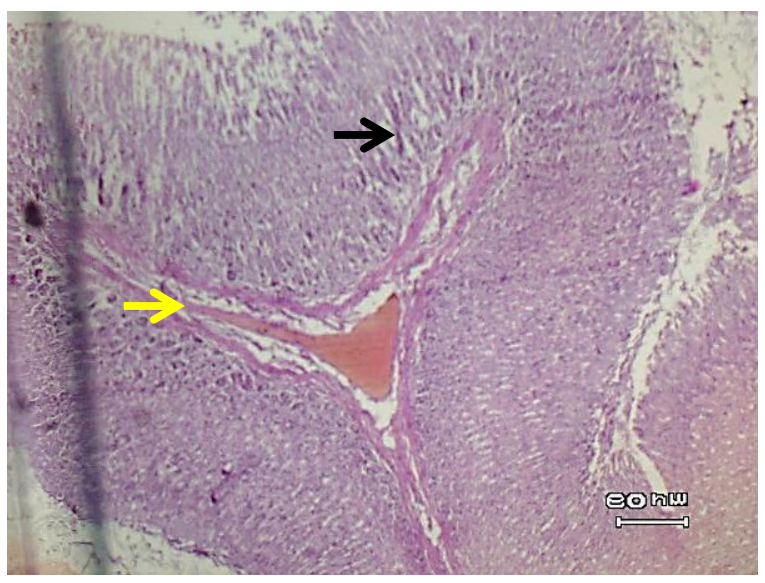

Gambar 2.4. Gambaran mikroskopik lambung tikus wistar kelompok B. Tampak edema jaringan dan vasodilatasi (Panah hitam: edema; panah kuning: pembuluh darah yang melebar)

Pada tikus wistar kelompok C diperoleh gambaran histopatologik yang memperlihatkan tanda-tanda radang, yaitu infiltrasi sel-sel radang PMN, limfosit, sel plasma dan eosinofil pada lapisan mukosa, submukosa, muskularis, hingga serosa. Terdapat pula jaringan stroma hiperemis, pelebaran pembuluh darah kapiler serta edema jaringan. Namun demikian, tandatanda radang pada tikus kelompok ini tampak lebih ringan dibandingkan dengan peradangan lambung tikus pada kelompok B. Lapisan mukosa tampak rata, tidak terlihat erosi mukosa. Pada kelompok ini terlihat banyak sel-sel regenerasi. (Lihat Gambar 3).

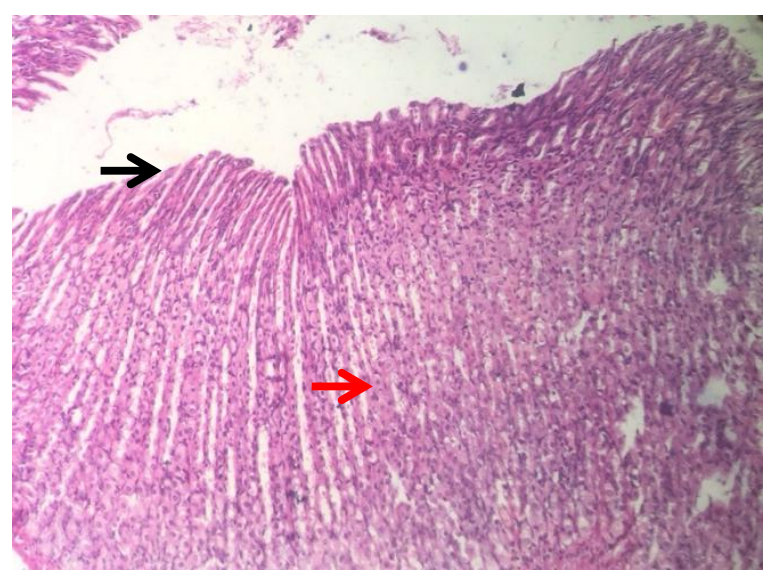

Gambar 3.1. Gambaran mikroskopik lambung tikus wistar kelompok C. Tampak epitel permukaan mukosa yang rata dan sel-sel regenerasi (Panah hitam: mukosa rata; panah merah: sel regenerasi)

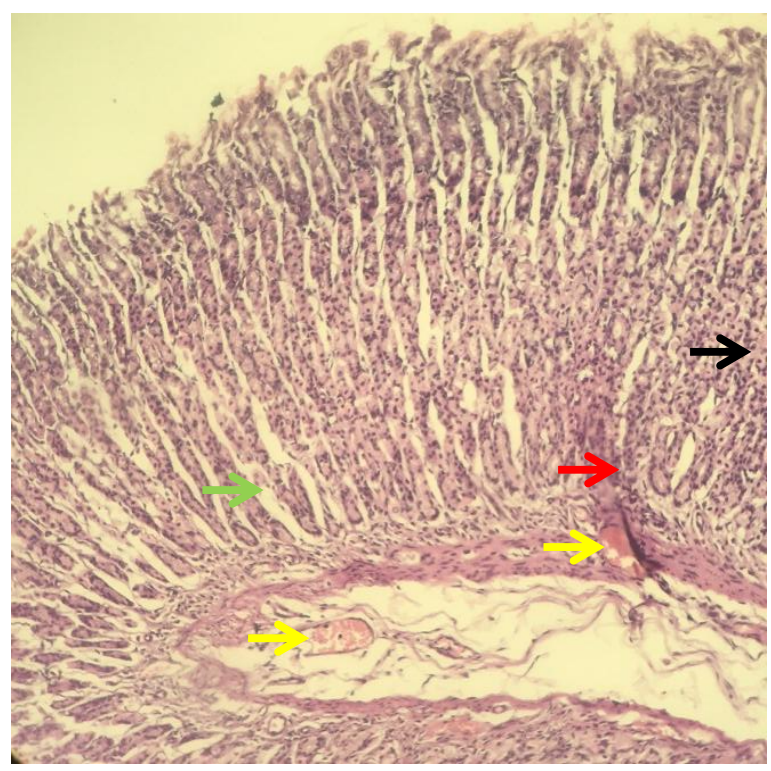

Gambar 3.2. Gambaran mikroskopik lambung tikus wistar kelompok C. Tampak sel-sel radang, vasodilatasi, edema, dan sel-sel regenerasi (Panah merah: sel-sel radang; panah kuning: pembuluh darah yang melebar; panah hijau: edema; panah hitam: sel regenerasi) 


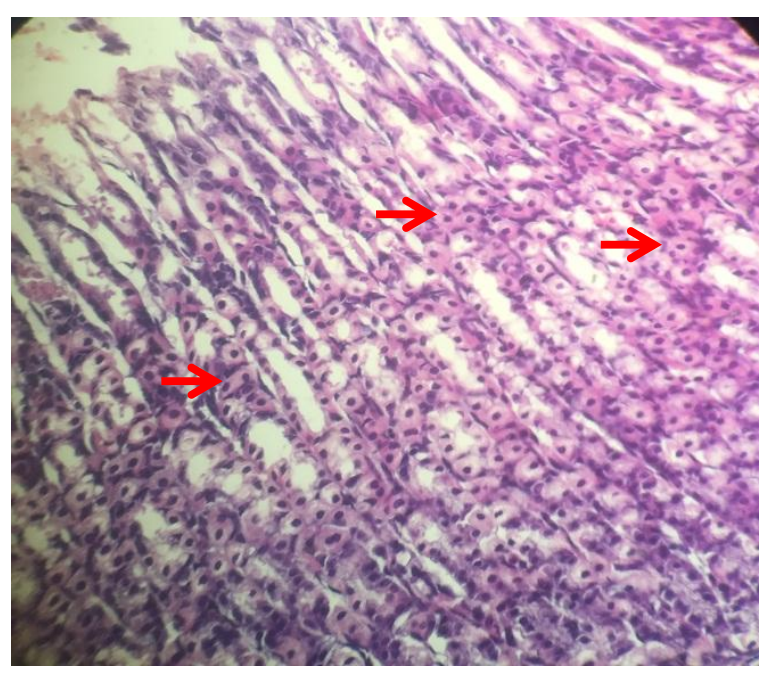

Gambar 3.3 Gambaran mikroskopik lambung tikus wistar kelompok C. Tampak sel-sel regenerasi yang banyak pada lapisan mukosa (Panah merah: sel regenerasi)

\section{BAHASAN}

Berdasarkan pengalaman empiris, susu kental manis sering dikonsumsi oleh pasien gastritis untuk meredakan keluhan nyeri penderita. Rasa manis dan $\mathrm{pH}$ dari susu kental manis diduga menjadi hal yang mendasari perbaikan keluhan dari pasien gastritis. Selain itu, kandungan oligosakarida susu memiliki efek antipatogenik terhadap saluran cerna. ${ }^{1,2}$ Asam mefenamat, salah satu obat AINS, diketahui mengganggu sawar mukosa lambung sehingga dapat mencetus peradangan mukosa lambung., ${ }^{3,5}$ Penelitian ini memberikan data mengenai gambaran histopatologik lambung tikus wistar yang diberikan susu kental manis dan diinduksi asam mefenamat.

Tikus yang tidak mendapatkan perlakuan atau kontrol negatif (kelompok A) memiliki gambaran histologik lambung yang sesuai dengan ciri-ciri lambung normal, yaitu terdiri dari lapisan mukosa, submukosa, muskularis, dan serosa. ${ }^{6}$ Kelompok ini juga menunjukkan adanya sedikit sel-sel radang pada lapisan mukosa. Sel-sel radang dalam jumlah sedikit ditemukan pada lambung normal karena makanan yang dikonsumsi diperkirakan terdapat mikroorganisme dan/atau bahanbahan yang bersifat iritatif terhadap saluran cerna.

Tikus pada kelompok perlakuan yang diberi asam mefenamat 23,25 mg/tikus/hari selama 7 hari (kelompok B) menunjukkan gambaran histopatologik gastritis akut, yaitu infiltrasi sel-sel radang pada lapisan mukosa sampai serosa, hiperemis, pelebaran pembuluh darah kapiler, dan edema. Peradangan lambung tersebut terjadi akibat induksi asam mefenamat. Asam mefenamat menghambat sintesis prostaglandin yang menyebabkan peningkatan keasaman lambung dan penurunan sekresi mukus (sebagai pelindung mukosa lambung)., Akibatnya sistem pertahanan dari lambung terganggu dan terjadilah proses peradangan akut. $^{4}$

Proses peradangan akut memiliki dua komponen utama yaitu perubahan vaskular dan emigrasi leukosit dari mikrosirkulasi. Perubahan vaskular pada inflamasi akut ditandai dengan peningkatan aliran darah dan penghambatan lokal pada aliran darah kapiler akibat dilatasi kapiler dan arteriol. ${ }^{7}$ Pada penelitian ini didapatkan adanya dilatasi beberapa pembuluh darah, sesuai dengan teori mengenai perubahan vaskular pada proses peradangan akut. Perubahanperubahan vaskular tersebut menyebabkan peningkatan permeabilitas vaskular menghasilkan suatu eksudat cairan ekstravaskular yang kaya protein sehingga terbentuk akumulasi cairan yang disebut edema, seperti yang terlihat pada gambaran histopatologik lambung tikus kelompok ini. $^{7}$

Pada proses peradangan akut terjadi emigrasi leukosit dari mikrosirkulasi dan akumulasinya di fokus jejas. Leukosit yang mulanya berada di dalam sirkulasi melekat pada endotel melalui molekul adhesi, kemudian meninggalkan mikrovaskular dan bermigrasi ke tempat cedera di bawah pengaruh agen kemotaktik untuk membersihkan agen yang menginvasi. Leukosit yang bekerja pada radang akut umumnya ialah leukosit polimorfonuklear (PMN/neutrofil). Neutrofil, monosit, eosinofil, dan berbagai 
jenis limfosit menggunakan molekul yang berbeda untuk proses rolling dan adhesi. Jenis leukosit yang direkrut tergantung pada sifat rangsang dan usia tempat peradangan. ${ }^{7}$ Hal ini dapat menjelaskan berbagai jenis leukosit yang ditemukan pada kelompok perlakuan B, yaitu leukosit PMN, limfosit, eosinofil, monosit, dan sel plasma.

Pada tikus kelompok B juga ditemukan gambaran erosi pada epitel permukaan mukosa lambung. Erosi epitel terjadi akibat induksi asam mefenamat sehingga menyebabkan kerusakan parah pada mukosa lambung. Asam mefenamat, salah satu jenis obat AINS, merusak mukosa lambung melalui dua mekanisme yaitu topikal dan sistemik. Kerusakan mukosa secara topikal terjadi karena AINS bersifat asam dan lipofilik, sehingga mempermudah terperangkapnya ion hidrogen masuk mukosa dan menimbulkan kerusakan. ${ }^{8,9}$ Ion hidrogen yang diserap ke dalam mukosa mengaktifkan pepsinogen menjadi bentuk aktif yaitu pepsin. Pepsin berperan dalam pencernaan protein dan dapat mencerna struktur-struktur protein sel sehingga dapat menghancurkan mukosa dan terjadi erosi. ${ }^{10}$ Pada penelitian ini, paparan asam mefenamat dosis maksimal pada tikus $(23,25 \mathrm{mg} / \mathrm{hari})$ selama 7 hari diperkirakan menyebabkan kerusakan topikal/lokal pada mukosa lambung dan memperlihatkan gambaran erosi epitel mukosa lambung.

Selain tanda-tanda radang, pada lambung tikus kelompok $\mathrm{B}$ juga tampak tanda-tanda pemulihan jaringan yang ditandai dengan adanya sel-sel regenerasi meskipun dalam jumlah sedikit. Regenerasi sel adalah pembentukan sel baru untuk menggantikan sel yang mati/rusak. Regenerasi sel epitel diregulasi oleh prostaglandin dan faktor pertumbuhan. Selain itu, hormon gastrin yang disekresikan oleh sel endokrin (sel G) pada foveola gastrica berperan dalam mendorong pertumbuhan pada mukosa lambung. ${ }^{10}$ Berdasarkan kemampuan regenerasi serta hubungan terhadap siklus sel, sel pada jaringan epitel selapis silindris (epitel kolumnar) permukaan lambung digolongkan ke dalam kelompok sel labil, yaitu sel yang terus membelah. Regenerasi pada kelompok sel labil terjadi dari suatu populasi sel stem dengan kemampuan berproliferasi yang tidak terbatas. Sel berproliferasi melalui beberapa fase yaitu fase pertumbuhan prasintesis $1\left(\mathrm{G}_{1}\right)$, fase sintesis DNA $(\mathrm{S})$, fase pertumbuhan pramitosis $2\left(\mathrm{G}_{2}\right)$, dan fase mitosis (M). ${ }^{11}$ Pada lambung tikus kelompok $\mathrm{B}$ juga terlihat sel-sel yang sedang dalam proses mitosis, dimana hal ini menandakan bahwa sedang terjadi proses regenerasi sel.

Tikus pada kelompok perlakuan yang diberi asam mefenamat 23,25 $\mathrm{mg} /$ tikus/hari dan susu kental manis $0,8 \mathrm{ml}$ selama 7 hari (kelompok C) secara umum masih memperlihatkan tanda-tanda gastritis akut seperti yang terlihat pada tikus kelompok B (hanya diberi asam mefenamat 23,25 mg/tikus/hari selama 7 hari). Namun demikian, gambaran erosi mukosa lambung sudah tidak terlihat pada tikus kelompok C. Gambaran mukosa lambung yang didapatkan ini diduga terjadi karena efek protektif SKM terhadap kerusakan topikal/lokal yang disebabkan AINS. Susu kental manis yang bersifat amfoter diduga berperan dalam melindungi mukosa lambung tikus wistar dari kerusakan akibat asam mefenamat. ${ }^{1,2}$ Susu bersifat amfoter sehingga dapat bersifat basa di lingkungan yang sangat asam. ${ }^{1}$ Sifat basa susu ini diduga berperan dalam mengurangi keasaman suasana lumen lambung yang sangat asam. Keasaman yang menurun (ion $\mathrm{H}^{+}$ berkurang) mengurangi aktivasi pepsinogen menjadi pepsin sehingga terjadi penurunan aktivitas pepsin dalam mencerna struktur protein sel dan menyebabkan penghancuran/kerusakan mukosa. ${ }^{10}$ Hal ini diduga dapat menjelaskan permukaan mukosa yang baik/rata (tidak mengalami erosi maupun atrofi) pada lambung tikus kelompok $\mathrm{C}$. Perlu dilakukan penelitian lebih lanjut 
untuk mengetahui bagaimana SKM dapat melindungi mukosa lambung dari kerusakan akibat bahan iritatif.

Secara umum sel-sel regenerasi yang aktif pada mukosa lambung tikus kelompok $\mathrm{C}$ tampak lebih banyak dibandingkan dengan yang terlihat pada tikus kelompok B. Banyaknya sel-sel regenerasi pada mukosa lambung tikus kelompok $\mathrm{C}$ menandakan proses pemulihan jaringan pada kelompok ini terjadi lebih cepat/dini dibandingkan dengan tikus pada kelompok B. Perlu dilakukan penelitian lebih lanjut untuk mengetahui apakah proses regenerasi sel ini terjadi secara fisiologis atau berhubungan dengan peningkatan sekresi hormon gastrin yang dapat mendorong pertumbuhan sel pada mukosa lambung karena diberi SKM setelah induksi bahan iritatif. ${ }^{10,11}$

Latar belakang penelitian ini ialah adanya bukti-bukti empiris mengenai penggunaan/konsumsi SKM dalam memperbaiki keluhan nyeri epigastrium pasien gastritis. Sampai saat ini belum ada referensi dan penelitian yang jelas menyatakan bahwa SKM mempengaruhi (meringankan) keluhan pasien gastritis. Hal ini dapat juga bersifat subyektif, hal lain yang dapat dipertimbangkan ialah mengenai pengaruh rasa manis dari SKM terhadap rasa nyeri yang dialami penderita. Rasa SKM yang manis disebabkan oleh kandungan sukrosa yang banyak. Berdasarkan penelitian oleh Yamamoto et al (2000), pemberian sukrosa pada tikus meningkatkan kadar $\beta$-endorfin pada cairan serebrospinal (CSS) dan plasma sehingga dapat menghambat respon nyeri. ${ }^{12}$ Konsumsi makanan dan minuman kaya gula merangsang pelepasan euphoric endorphins dan dopamin di dalam nucleus accumbens. ${ }^{13}$ Telah diketahui endorfin merupakan opiat endogen yang berfungsi sebagai neurotransmiter analgesik. ${ }^{14}$ Dengan demikian, rasa manis diperkirakan berperan dalam menutupi/mengurangi rasa nyeri sehingga dapat menurunkan tingkat rasa nyeri yang dirasakan penderita.
Namun hal ini tidak diteliti pada penelitian ini.

Hasil penelitian ini menunjukkan bahwa susu kental manis dapat mengurangi peradangan pada lambung akibat induksi asam mefenamat. Selain itu, SKM dapat mempercepat proses pemulihan/regenerasi jaringan lambung akibat kerusakan oleh asam mefenamat. Dengan demikian, dapat dikatakan bahwa pemberian SKM berperan dalam proteksi mukosa lambung terhadap efek topikal/lokal obat AINS pada mukosa lambung, serta membantu terjadinya pemulihan jaringan/mukosa lambung yang lebih dini.

Keterbatasan penelitian ini ialah jumlah sampel, waktu, dan biaya untuk melakukan analisis statistik dari data yang didapatkan. Penelitian ini hanya bersifat deskriptif dari analisis preparat jaringan dengan hasil deskriptif kualitatif. Akan lebih baik jika data yang didapatkan diolah secara statistik (kuantitatif) agar hubungan antar variabel lebih jelas dan hasil lebih valid. Keterbatasan lainnya ialah kurangnya referensi dan penelitianpenelitian sebelumnya mengenai mekanisme SKM sebagai bahan protektif tubuh terhadap bahan iritatif.

\section{SIMPULAN}

Berdasarkan penelitian ini dapat disimpulkan bahwa gambaran histopatologik lambung tikus wistar (Rattus norvegicus) yang diinduksi asam mefenamat dan diberi susu kental manis menunjukkan tanda-tanda gastritis akut yang lebih ringan dan regenerasi sel yang lebih baik dibandingkan dengan yang terlihat pada lambung tikus wistar yang tidak diberi susu kental manis setelah induksi asam mefenamat. Jadi, dapat dikatakan bahwa pemberian susu kental manis berperan dalam proteksi dan pemulihan/regenerasi sel mukosa lambung terhadap efek topikal/lokal asam mefenamat. 
SARAN

1. Perlu dilakukan penelitian lebih lanjut untuk mengetahui bagaimana mekanisme susu kental manis dapat melindungi mukosa lambung dari kerusakan akibat bahan iritatif dengan dosis dan waktu yang berbeda.

2. Perlu dilakukan penelitian lebih lanjut untuk mengetahui apakah terdapat hubungan antara regenerasi sel yang terjadi lebih cepat/dini dengan sekresi hormon gastrin pada mukosa lambung karena diberi SKM setelah induksi bahan iritatif.

3. Perlu dilakukan penelitian mengenai pengaruh konsumsi susu kental manis terhadap tingkat nyeri penderita gastritis.

4. Perlu dilakukan penelitian dengan analisis statistik mengenai pengaruh pemberian susu kental manis terhadap gambaran histopatologik lambung yang diinduksi bahan iritatif.

\section{DAFTAR PUSTAKA}

1. Saleh E. Dasar Pengolahan Susu dan Hasil Ikutan Ternak [Diktat]. [Medan]: Fakultas Pertanian Universitas Sumatera Utara; 2004.

2. Urashima T, Kitaoka M, Asakuma S, Messer M. Milk Oligosaccharides. In: McSweeney PLH, Fox PF, editors. Advanced Dairy Chemistry, Volume 3: Lactose, Water, Salts and Minor Constituents. Cork, Ireland: University College; 2009. p. 295-331.

3. Lindseth GN. Gangguan Lambung dan Duodenum. Dalam: Price SA, Wilson LM, Patofisiologi: Konsep Klinis Proses-proses Penyakit. Volume 1. Edisi 6. Jakarta: ECG; 2005. h. 417-36.

4. Kumar, Cotran, Robbins. Rongga Mulut dan Saluran Gastrointestinal. Dalam: Hartanto H, Darmaniah N, Asroruddin M, editor. Buku Ajar Patologi. Edisi ke-7. Jakarta: Penerbit Kedokteran EGC, 2007; h. 622-31.

5. Wilmana F, Gan S. Analgesik-Antipiretik, Analgesik Anti-Inflamasi Nonsteroid, dan Obat Gangguan Sendi Lainnya. Dalam: Gunawan SG, Nafrialdi RS,
Elysabeth, editors. Farmakologi dan Terapi. Edisi 5. Jakarta: Balai Penerbit FKUI; 2012. h. 230-46.

6. Eroschenko, Victor P. Atlas Histologi diFiore: dengan Korelasi Fungsional. Edisi ke-11. Jakarta: ECG; 2010. h. 274-301.

7. Kumar, Cotran, Robbins. Inflamasi Akut dan Kronik. Dalam: Hartanto $\mathrm{H}$, Darmaniah N, Asroruddin M, editor. Buku Ajar Patologi. Edisi ke-7. Jakarta: Penerbit Kedokteran EGC, 2007; h. 35-56.

8. Tarigan P. Tukak Gaster. Dalam: Sudoyo AW, Setiyohadi B, Alwi I, Simadibrata M, Setiati Seditor, editor. Buku Ajar Ilmu Penyakit Dalam. Edisi ke-4 Jilid.I. Jakarta: Pusat Penerbitan Ilmu Penyakit Dalam FKUI. 2006. p.33848.

9. Gosal F, Paringkoan B, Wenas NT. Patofisiologi dan Penanganan Gastropati Obat Antiinflamasi Nonsteroid. J Indon Med Assoc. 2012;62:444-9.

10. Sherwood, Lauralee. Sistem Pencernaan. Dalam: Pendit BU, Yesdelita N, alih bahasa, editor. Fisiologi Manusia: dari Sel ke Sistem. Edisi ke-6. Jakarta: EGC; 2011. h. 641-66.

11. Kumar, Cotran, Robbins. Pemulihan Jaringan: Regenerasi dan Fibrosis Sel. Dalam: Hartanto H, Darmaniah N, Asroruddin M, editor. Buku Ajar Patologi. Edisi ke-7. Jakarta: Penerbit Kedokteran EGC, 2007; h. 65-75

12. Yamamoto T, Sako N, Maeda S. Effects of Taste Stimulation on BetaEndorphin Levels in Rat Cerebrospinal Fluid and Plasma. Physiol Behav. 2000; 69(3):345-500.

13. Fortuna JL. Sweet Preference, Sugar Addiction, and Familiar History of Alcohol Dependence: Shared Neural Pathways and Genes. J Psychoactive Drugs. 2010; 42(2):147-51.

14. Sherwood, Lauralee. Susunan Saraf Tepi: Divisi Aferen Indera Khusus. Dalam: Pendit BU, Yesdelita N, alih bahasa, editor. Fisiologi Manusia: dari Sel ke Sistem. Edisi ke-6. Jakarta: EGC; 2011. h. 211. 